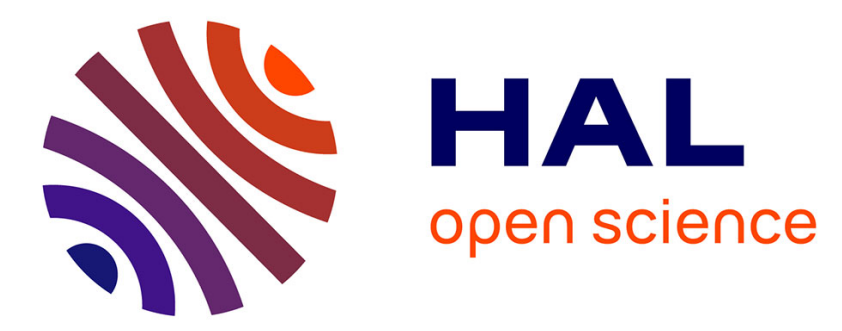

\title{
Civil Construction Workers: Technical Training for Complying with a Market Demanding Sustainability
}

Carla Caprara Parizi, Irenilza De Alencar Nääs, Sivanilza Teixeira Machado, Denise Dupont Bernini

\section{To cite this version:}

Carla Caprara Parizi, Irenilza De Alencar Nääs, Sivanilza Teixeira Machado, Denise Dupont Bernini. Civil Construction Workers: Technical Training for Complying with a Market Demanding Sustainability. IFIP International Conference on Advances in Production Management Systems (APMS), Sep 2014, Ajaccio, France. pp.278-285, 10.1007/978-3-662-44736-9_34 . hal-01387879

\section{HAL Id: hal-01387879 \\ https://inria.hal.science/hal-01387879}

Submitted on 26 Oct 2016

HAL is a multi-disciplinary open access archive for the deposit and dissemination of scientific research documents, whether they are published or not. The documents may come from teaching and research institutions in France or abroad, or from public or private research centers.
L'archive ouverte pluridisciplinaire HAL, est destinée au dépôt et à la diffusion de documents scientifiques de niveau recherche, publiés ou non, émanant des établissements d'enseignement et de recherche français ou étrangers, des laboratoires publics ou privés.

\section{(c)(1)}

Distributed under a Creative Commons Attribution| 4.0 International License 


\title{
Civil construction workers: technical training for complying with a market demanding sustainability
}

\author{
Carla Caprara Parizi (ccapraraparizi@gmail.com), Irenilza de Alencar Nääs (Irenil- \\ za@gmail.com), Sivanilza, Teixeira Machado (sivateixeira@yahoo.com.br), Denise \\ Simões Dupont Bernini (denise.unip@gmail.com) \\ Paulista University. Dr Bacelar St, 1212, São Paulo, Brazil.
}

\begin{abstract}
Brazilian building construction involves millions of formal and informal workers without technical skills and/or specific training. This study aimed to analyze building workers technical profile and estimate its impact in both their performance and the efficiency of sustainable actions within the companies/contractors. A questionnaire was developed and applied to workers, in order to search their school level, practical experience (basic skills), level of technical qualification (technical skills), level of addiction, wages, construction techniques, program on sustainability, productivity, training programs, level of re-work, amount of waste, overtime performed, difficult in leadership, resistance to the use of equipment for individual safety, the level of accidents, and motivation factors. Results showed that most surveyed companies/contractors do not adopt sustainability programs for worker's education; but those that offer these programs were not successful. Most companies offer more particular training for specific activities, but they are insufficient for the worker, and it only solves a restricted need. However, the lack education that enables learning and reduces the performance also decreases the changes of implementing environmental directed training programs.
\end{abstract}

Keywords: contractors, housing builders, education, sustainability

\section{Introduction}

Brazilian housing construction segment employs 2 million of formal workers, and near 5 million informal workers, with 208,537 thousand formal companies, and from this amount 14 thousand are located in the city of São Paulo [1]. This sector is made of a complex and heterogeneous chain encompassing suppliers, developers, contractors, laboratories using an intensive labor arising from the lower segment of society, and usually low skilled. Much of the construction workers develop their professional activities by observing other more qualified colleagues, and the practical teaching is taught by the most experienced to the others. However, this procedure is not acceptable, and in many cases, the process of repetition is responsible for questionable training, making the employees with wrong practices the teachers.

This scenario generally leads to re-work and construction mistakes which need to be re-done, contributing significantly to generate waste of materials and time. Im-

adfa, p. 1, 2011.

(C) Springer-Verlag Berlin Heidelberg 2011 
Civil construction workers: the importance of training for complying with a sustainable market

provements are needed in order to meet the demand for sustainability through technological innovations, and it is possible to minimize losses and maximize productivity. However, in order to carry on programs on sustainable development on the construction area, more trained workers are needed. Sustainability concepts in this segment bring up discussions focused on topics related to the quantities of waste generated during the construction process, and it is necessary to maintain a balance between the development of the construction environment and the natural environment [2].

This study aims to analyze the profile of the labor technical qualification in housing building and the impact of the workers' skills in improving job performance, as well as their participation in sustainability programs offered by the builders/contractors.

\section{Methodology}

A field study was carried out applied to specialists and field civil engineers, corresponding to a total of 26 house building companies/contractors, with a focus on the skills of construction teams from Dec. /2013 to Feb./2014. The field study was done using a closed questionnaire with 18 questions developed with the objective of drawing the worker' profile in housing construction. The asked questions were related to the number of years in school, level of basic skills, level of technical training, education degree, if there was addiction issues, wage level, method of construction adopted, sustainable methods adopted, productivity, training programs, amount of re-work made, amount of waste generated, extra-hours worked difficulties in leadership, resistance to the use of safety equipment, and motivation. The level of basic skill was related to knowledge the worker learned by observing others. Technical training was considered as the skills learned by any means of formal teaching related to their tasks. The training offered by the building companies is related to basic best practices.

For data analysis, we used the technique of the frequency distribution, allowing the visualization of the percentage of responses answered to the questionnaire. Descriptive statistics and Pearson correlation were applied adopting a significance level of $\mathrm{p}$ $<0.05$. Data were processed using the computer software $\mathrm{SAS}^{\circledR}$ Version 9.0, routines PROC SUMM and PROC CORR, respectively.

\section{Results and Discussion}

\section{1 - Overall scheme of house building in Brazil}

From the questions answered $38.4 \%$ adopted the construction in reticular reinforced concrete and $61 \%$ used reinforced masonry. Despite the higher percentage is in structural masonry, reticular reinforced concrete is still mostly used in Brazil [3], as it allows bolder structures than others. This construction system is often used as it also allows changes in the original project, and adaptations along the construction, which permits a certain level of tolerance on the labor quality during the construction pro- 
cess. However, waste is very high in this process, and re-work could be avoided. The structural masonry is usually more rational; it increases the worker productivity and reduces wastes [4]. In the present study the waste from both construction processes was used to analyze labor efficiency. In the construction systems labor performance is assessed in man-hour $/ \mathrm{m}^{2}(44 \%)$, and in percentage of work finished in relation to the time estimated in the initial project $(48 \%)$. It also can be assessed using other units such as vol/time, area/time, which in this case represented $8 \%$ of the sample. Most work teams do not adopt sustainability programs or program focusing in environmental education during the construction $(84.6 \%$ ), and there is only $11.4 \%$ with some kind of waste management program, such as Environmental Education, and Social Inclusion through Waste Management. The Union of Construction Industry (SINDUSCON) produces booklets for workers, whose intention is to educate them towards sustainability issues. However, tenacious actions in worker education still are needed and must be incorporated by means of rules and a systematic consciousness. Some control mechanisms are also needed to reinforce actions adoption. Over $60 \%$ of the workforce in construction has education below the elementary school, $24.5 \%$ have secondary education, and $12.2 \%$ has some level of training.

Regarding the salary range, nearly $50 \%$ of the teams receive up to 3 minimum wages, which corresponds to approximately US\$ 945.00. Thirty percent of the total answers earn up to five salaries, $12 \%$ between 5:07 and $7 \%$ receive wages above 7 minimum wages (the minimum wage $\sim$ US\$ 315.00). Salary is the key factor on labor productivity, but it does not necessarily imply in high productivity, when the wage is adequate [5]. According to [6] construction companies offer high salaries in exchange for good productivity rate, and this action has not made a good incentive for effective results. These practices are an incentive towards individual actions. The average workers' wages rose at a rate of $7.6 \%$ in 2009 , while the rate of worker productivity was $4.2 \%$ [1]. Therefore, the wage growth was beyond productivity. This might be due to the shortage of workforce in São Paulo state. In the case of small companies or contractors, where the rate of productivity is equivalent to one third of the largest companies, this may represent a significant challenge. Other authors [7] assigned weights to the factors leading to worker productivity, which represents the strongest influence on productivity such as 1) the skills and experience of the workforce $(0.931), 2)$ the management $(0.916), 3)$ planning $(0.835), 4)$ the motivation of workers $(0.829)$, and 5) the availability of materials (0.822). These authors suggest that to improve the sector more qualified professionals performing the most difficult, complex tasks are needed; and that managers should make a commitment to productivity in all their actions, including waste reduction training. According to [8] to maximize productivity is necessary to examine the factors affecting this theme which are rarely independent. Low productivity is generally attributed to several factors, including lack of bonding and discontinuity of the worker' technical qualification process.

\section{2 - Basic skills and level of training analysis}

Analyzing the level of experience and the team' basic skills, a positive correlation of 0.57 ( $p=0.002)$ was found, which indicated that the level of basic knowledge may increase or decrease depending on the level of technical skills (Table 1). This result is 
Civil construction workers: the importance of training for complying with a sustainable market

consistent with the findings of previous research [4]. In this research after an investment in training $(60 \%$ within the companies, $58 \%$ by Senai-Nat. Ind. Apprent Service- workforce, $52 \%$ by especially training companies, and $37 \%$ by the Union) the following return were detected, $16 \%$ considered the training enough and satisfactory, $52 \%$ considered it adequate but with unsatisfactory initiatives; and $31 \%$ considered it insufficient. This suggests that although the training is crucial to meet worker' efficiency needs, those lacking formal education cannot acquire new techniques through this technical training. In another study, in the city of Curitiba [9], results indicated that the worker learn their skills from their parents (5\%), from another informal jobs (23\%), by attending vocational courses (7\%), through technical trainings in companies $(16 \%)$, and other forms including self-learning or watching other professionals, (49\%). This scenario indicates that with this workers profile, chances are high that the work execution might be full of uncertain actions leading to further defects or rework. Workers with low level of education (100\%) also presented low level of technical skills. Workers with average and high level of experience are the best qualified for both levels 4 and 5 (75\%; Table 1).

Table 1. Level of experience in relation to the worker qualification in construction (\%).

\begin{tabular}{cccccccc}
\hline & & \multicolumn{7}{c}{ Technical training } & Total \\
\hline & Level* & $\mathbf{1}$ & $\mathbf{2}$ & $\mathbf{3}$ & $\mathbf{4}$ & $\mathbf{5}$ & \\
& $\mathbf{1}$ & 100 & - & - & - & - & 100 \\
& $\mathbf{2}$ & 100 & - & - & - & - & 100 \\
& $\mathbf{3}$ & 6.3 & 6.3 & 12.5 & 43.8 & 31.3 & 100 \\
& $\mathbf{4}$ & - & - & 28.6 & 28.6 & 42.9 & 100 \\
& $\mathbf{5}$ & - & - & - & - & - & - \\
& *1=very low; 2=low; 3=average; 4=high; 5=very high. & & &
\end{tabular}

This form of learning is individual; it does not lead to an effective organizational development and a vision of the whole to work. The concept of Learning Organization could be introduced for the benefit of all involved. According to [10] the learning organization's principle modify individual behavior continuously as a result of their socialization, taking into account the culture of the organization, creating new routines and new shares. To [11] the learning organization is a strategy to improve processes in the construction area, but most construction contractors' focus on individualized but continuous learning. This concept gives rise to an important practical benefit as it provides the diagnostic procedures and / or ineffective tasks [12]. In the Brazilian scenario individual learning is insufficient (Table 2 and 3). According to the data from this study, $99 \%$ of the companies obtain the labor from other companies; therefore, it does not offer a culture of learning organization. Construction sites are generally mixed companies with varied objectives and philosophies.

\section{3 - Training and waste}

Brazilian construction industry seeks the difficult in meeting the national laws and resolutions, with a trend to increase levels of legal requirements, including restrictions 
on financing new projects. Environmental concern is not only a socio-environmental responsibility, but it is a complex and difficult requirement.

Data from Table 1 shows that $100 \%$ of workers with low basic skills also presented low learning skills and did not take proper advantage of technical training. Workers with mean to high level of knowledge and learning skills (mean level 3 and high level 4) were those which presented most qualification with practically 41 and $73 \%$, respectively. Approximately $80 \%$ of the cost was below $10 \%$, for a level of performance of the trained worker above the average $(3,4$ and 5$)$. Some teams presented $100 \%$ of rework cost above $31 \%$ for the levels of technical skills mean and high (Table 2). Similar results were found for material wasted along the construction (Table 3). Both tables (Table 2 and Table 3) present similar scenario. No relationship was found between workers technical and the material' wastes; or the amount of re-work during the housing construction process. Labor performed was simply related to the tasks previous contracted, which does not clearly include the need to reduction of material wastes or compliance with the sustainable construction. This result, which leads to large amount of waste and re-work agrees with [9], who found that construction segment in Brazil consumes $40 \%$ of natural resources, $40 \%$ of energy, and it generates $40 \%$ of residues related to human activities. Amongst the programs related to sustainability, the majority responded that there were environmental compensation programs, and re-forestation incentives; however, these programs do not educate the worker in relation to environmental issues. In repetitive activities, trained workers can perform their work, but it does not mean that the work is done in an efficient way. Final results can generate immediate re-work, implicating in greater investment of time, and it generates more waste of materials, and in the medium and long term it may reduce the life' property or yet promote its unsuitability. Workers' competence is, therefore, highly needed in housing construction companies.

Table 2. Percentage of costs with re-work, in relation to the level of level of performance of the technical trained worker $(\%)$.

\begin{tabular}{ccccccc}
\hline & \multicolumn{7}{c}{ Technical Training } & Total \\
\hline Re-work $(\%)$ & $\mathbf{1}$ & $\mathbf{2}$ & $\mathbf{3}$ & $\mathbf{4}$ & $\mathbf{5}$ & \\
\hline$<10$ & 22.2 & - & 22.2 & 22.2 & 33.3 & 100 \\
\hline $11<20$ & 16.7 & 8.3 & 8.3 & 33.3 & 33.3 & 100 \\
\hline $21<30$ & - & - & - & 50.0 & 50.0 & 100 \\
\hline $31<40$ & - & - & 100.0 & - & - & 100 \\
\hline$>41$ & - & - & - & 100.0 & - & 100 \\
\hline
\end{tabular}

1=very low; $2=$ low; $3=$ average; 4=high; $5=$ very high.

Professional competence [13] is defined as the development of information (in conceptual terms or ideas), behavior (actions), and skills (use of learned experience), and its use is desirable in specific actions within the dimensions of education, politics, ethics, culture and environment, when analyzing personal and interpersonal relationships. In general, individuals with low education do not understand issues related to ethics or other concepts within the social and economic context, and the basic citizen- 
Civil construction workers: the importance of training for complying with a sustainable market

ship aspect of protecting society from any damage. In this direction, a certain level of education is required to understand sustainability. In the last evaluation of the Program of International Student Assessment [14], Brazil stayed in the 53rd position amongst 65 countries. According to [15] quality of education influences positively in the economic growth and; therefore, the country has yet much to invest in education in order to change various aspects of its development.

Table 3. Cost percentage of material wasted in relation to the level of achievement acquired by the worker with technical training $(\%)$

\begin{tabular}{ccccccc}
\hline \multirow{2}{*}{ Material wasted (\%) } & $\mathbf{1}$ & $\mathbf{2}$ & $\mathbf{3}$ & $\mathbf{4}$ & $\mathbf{5}$ & Total \\
\hline$<10$ & 22.2 & - & 22.2 & 22.2 & 33.3 & 100 \\
$11<20$ & 14.3 & 7.1 & 14.3 & 28.6 & 35.7 & 100 \\
$21<30$ & - & - & - & - & - & 0 \\
$31<40$ & - & - & - & 100 & - & 100 \\
$>41$ & - & - & - & - & - & 0 \\
\hline
\end{tabular}

1=very low; 2=low; 3=average; 4=high; 5=very high.

\section{4 - Labor safety and working hours}

When analyzing labor safety $70 \%$ of the surveyed workers do not want to use safety equipment. Positive correlation was found with the lack of safety equipment use and occurrence of accidents $(\mathrm{p}=0.0001)$. In general, $65 \%$ of accidents were related to workers involved in work between 8 to $9 \mathrm{~h}$ daily (Figure 1). This result may be easily justified by the physical exhaustion of the worker, when the recommended time during the work is of $8 \mathrm{hs}$ daily. In addition, many teams work above the permitted hours (due to the time set for the construction), requiring more effort from the teams. However, working overtime interferes negatively on worker productivity [16].

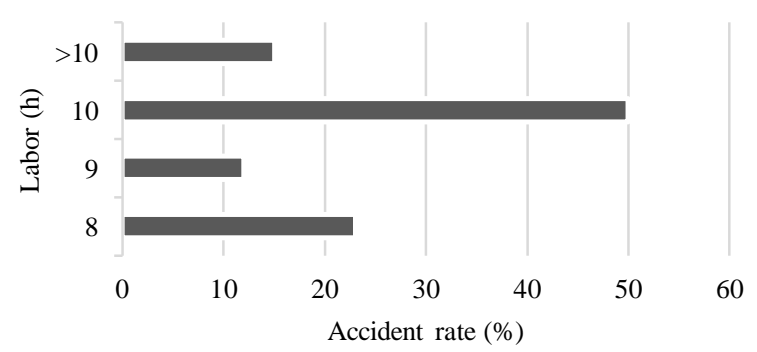

Fig. 1. Accident rate in relation to worked hours.

The most interesting comment in the answers in the questionnaire regarding accident rates was that efforts to reduce the number of accidents has only an economic 
appeal, and there is not a real concern with the physical and psychological integrity of the worker and his family. It has also been seen that there is an occurrence of workers with alcohol addiction in the construction field. In this study, we found that $50 \%$ of the surveyed teams have workers with some detected chemical addiction negatively influencing the labor performance. Construction workers do not value their job, they consider their work as "risky", "heavy", "undervalued", and "with no future". While this type of work seems to be the last resort used as a means of survival by untrained workers, they feel socially devalued, without formal education, within a low socioeconomic status $[17,18]$. Therefore, they run out of satisfaction and do not perform their assignments properly, and do not have good communication with their immediate supervisors.

\section{Conclusions}

When workers have the basic skill, they have better performance throughout technical training. However, workers' training has not been fully reached regarding sustainability issues, mainly in issues related to waste of materials and re-work tasks. Job performance is poor due to lack in proper training.

Most companies/contractors surveyed do not adopt sustainability programs within worker' education, but those that offer these programs were not successful. Specific training was proved insufficient, as they supply only a small portion of the education gap, and they do not necessarily enable learning items related to environmental issues.

Organized actions and control mechanisms should be integrated into the construction services to attend a market that demands faster actions, yet not losing sight of the questions facing the sustainability and quality. Everything indicates that use of the learning organization concept would the businesses since adapted to Brazilian scenario, raised in this work. The suggestion is that subcontracts establish strong partnerships with the contractor about to establish the same organizational cultures focused naturally hand-intensive operational.

\section{Acknowledgement}

The authors thank CAPES - Coordination of Improvement of Higher Education in Brazil - and Paulista University - UNIP, for the scholarship.

\section{References}

1. FIESP/CBIC - Fed. Ind. Est. S. Paulo/ C. Bras. da Ind. da Construção. A produtividade da Construção Civil Brasileira (2012). CBIC http://paraconstruir.wordpress.com/2012/07/10/relatorio-cbic-sobre-produtividade-daconstrucao-civil/ (accessed on: March 2014).

2. Al-Hajj A.; Hamani K. Material Waste in the UAE Construction Industry: Main Causes and Minimization Practices. School of the Built Environment, Heriot-Watt 
Civil construction workers: the importance of training for complying with a sustainable market

Univ. Dubai Campus, UAE Pub. online: (16 Nov. 2011). https://pureapps2.hw.ac.uk/portal/files/1954110/ASCW_IWMM_in_UAE_Journal_A EDM_Sep11_revised_AAH.pdf (accessed on: March 2014).

3. Silva, M.M.A. Diretrizes para o projeto de alvenaria estrutural: contribuição ao uso. M.Sc. Dissert. Escola Poli. da Univ. de São Paulo (2003). www.teses.usp.br/teses/disponiveis/3/3146/.../DissertacaoMargarete.pdf (accessed on: February 2014).

4. Roman, H.R.; Mutti, C.N.; Araújo, H.N. Construindo em alvenaria estrutural. Ed.UFSC. Florianópolis. ISBN 8532801668, 978853280166183 p.(1999)

5. Kazaz A. E.; Ulubeyli S. Drivers of productivity among construction workers: A study in a developing country. In Building and Environment 39: 93 - 100 (2006).

6. Dalcul A.L. P. C.; Mirian O. Ruas R.L. Organização do trabalho: estudo de caso com empresas da construção civil de Santa Maria/RS. (5 Jul. 2002) http://hdl.handle.net/10183/19409 (accessed on: February 2014).

7. Mojahed, S.; Aghazadeh, F. Major factors influencing productivity of water and wastewater treatment plant construction: evidence from the deep south USA. International Journal of Project Management 26, 195-202 (2008).

8. Nasirzadeh, F.; Nojedehi P. Dynamic modeling of labor productivity in construction projects. International Journal of Project Management 31, 903-911 (2013).

9. Honorio D.E. Qualid. de vida do operário da Const. Civil e sua importância na qualidade e produtividade em obras. Masters' Diss, Fed.Univ.St.Cat., Brazil, (2002). https://repositorio.ufsc.br/handle/123456789/83250 (accessed on: December 2013).

10. Phan H. Philip. Knowledge creation in strategic alliances: Another look at organizational learning. Asia Pacific Journal of Management 17, 201-222 (2000).

11.Kululanga G.K.; Price A.D.F.; McCaffer R., Empirical Investigation of Construction Contractors' Organizational Learning. Journal of Construction Engineering and Management 128, 385-391 (2002).

12 . Pentland B.T. Information Systems and Organizational Learning: The Social Epistemology of Organizational Knowledge Systems. Accouting, Management \& Information Technology 5, 1-21 (1995).

13. ABRAMAT - Assoc. Bras. Ind. Mat. Construção. Capacitação e formação profissional na construção civil e mecanismos de mobilização de demanda. São Paulo USP - Depart. de Eng. de Const. Civil. (2007).

14. PISA 2009. Results. Available athttp://www.oecd.org/pisa/pisaproducts/46619703.pdf (accessed on: March 2014).

15. Hanushek, E.A.; Kimko, D.D. Scchooling, Labor-Force Quality, and the Growth of Nations? Aerican Economic Review 90,1184-1208 (2000).

16. Hanna, A.S.; Taylor, C.S.; Sullivan, K.T. Impact of extended overtime on construction labor. J. of Construction Engineering and Management 131, 734-739 (2005)

17. Iriart, J.A.B.; Oliveira R.P. Psicologia em Estudo. Representações do Trabalho entre trabalhadores informais da Construção Civil. Psicologia em Estudo 13, 437-445, (2008).

18. John, V.M.; Silva, V.G.; Agopyan, V. Agenda 21: uma proposta de discussão para o constru-business brasileiro. II ANTAC/UFRGS, Canela-RS, pp. 91-98 (2001) 